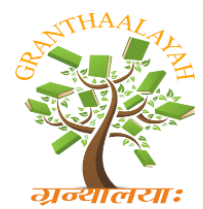

INTERNATIONAL JOURNAL OF RESEARCH GRANTHAALAYAH A knowledge Repository



Management

\title{
THE ROLE OF FORWARD MARKETS COMMISSION IN INDIAN COMMODITY MARKETS
}

\author{
Dr. Shree Bhagwat ${ }^{* 1}$, Angad Singh Maravi ${ }^{2}$ \\ *1 Asst. Prof., Department of Business Management, Dr. Harisingh Gour Central \\ Vishwavidyalaya, Sagar, Madhya Pradesh, INDIA \\ ${ }^{2}$ Research Scholar, Department of Commerce, Dr. Harisingh Gour Central \\ Vishwavidyalaya, Sagar, Madhya Pradesh, INDIA
}

\begin{abstract}
This paper examines the role of Forward Markets Commission (FMC) in Indian Commodity Markets. The Results show important developments of Forward Markets Commission. Commodity futures and derivatives have a crucial role to play in the price risk management process, especially in agriculture sector. The significance of commodity derivatives has increased in the current scenario. India has long history of trade in commodity derivatives. Organized commodity derivatives in India started as early as 1875, barely about a decade after they started in Chicago. Since 2003, when commodity futures' trading was permitted, commodity futures market in India has experienced an unprecedented boom in terms of the number of modern exchanges, number of commodities allowed for derivatives trading as well as the value of futures trading in commodities. There are 6 national and 16 regional commodity exchanges recognized and regulated by the FMC. Different types of commodities such as agricultural; bullion, plantation, energy etc. is traded on commodity exchanges in the country. So considering these points an attempt has been made to know the regulatory framework of commodity futures and derivatives market in India and various developments in Indian commodity market and commodity exchanges. This study is an attempt to investigate the performance of Forward Markets Commission in India and its role in Indian commodity market.
\end{abstract}

Keywords:

Commodity Derivatives and Futures Market, Commodity Exchanges, FMC, Ministry of Finance.

Cite This Article: Dr. Shree Bhagwat, and Angad Singh Maravi, "THE ROLE OF FORWARD MARKETS COMMISSION IN INDIAN COMMODITY MARKETS" International Journal of Research - Granthaalayah, Vol. 3, No. 11(2015): 87-105.

\section{INTRODUCTION}

Commodity trading in India has a long and rich history. The history of commodity Futures market in India dates back to the ancient times citied in Kautialya's 'Arthasastra', Words like, "Teji”, 
"Mandi", "Gali", and "Phatak" have been commonly heard in Indian markets for centuries which seems to be coined in $320 \mathrm{BC}$ and also referred in Forward Contracts (Regulation) Act, 1952 ; The first organized futures market in India was however established in 1875 under the aegis of the "Bombay Cotton Trade Association" to trade in cotton contracts. This was followed by establishment of futures markets in edible oilseeds complex, raw jute and jute goods and bullion. Post-independence, in the 1950s, India continued to struggle with feeding its population and the government increasingly restricting trading in food commodities. In independent India, the Forward Contracts (Regulation) Act was enacted in 1952 to regulate the commodity trading in forward and futures contracts. Just as SEBI regulates the stock exchanges, commodity exchanges are regulated by Forward Markets Commission (FMC); Forwards Market Commission works under the purview of the Ministry of Finance, Department of Economic Affairs. Forward Markets Commission is a regulatory body for commodity futures/forward trade in India. This was set up under the Forward Contracts (Regulation) Act of 1952. It is responsible for regulating and promoting futures/forward trade in commodities. At present, there are three tiers of regulations of forward/futures trading system exists in India, namely, Government of India, Forward Markets Commission (FMC) and Commodity Exchanges.

Government of India, in 2002-03, has demonstrated its commitment to revive the Indian agriculture sector and commodity futures markets. Prime Minister's Independence Day address to the nation on August 15, 2002, which enlisted nation-building initiatives, included setting-up of national commodity exchange among the important initiatives. The year 2002-03, certainly, was an eventful year in terms of regulatory changes and market developments that could set the agenda for development for the years to come. In 2003, a prohibition on futures trading in all commodities was lifted and recognition was granted to three national commodity electronic exchanges, the MCX, NCDEX and NMCE. The only financial product currently traded on commodity exchanges in India is futures. Forward contracts are traded in the Over-the-Counter (OTC) market. There are six national commodity exchanges: the Multi Commodity Exchange (MCX); the National Commodity and Derivatives Exchange (NCDEX); the National Multi Commodity Exchange (NMCE); the Indian Commodity Exchange; ACE Derivatives \& Commodity Exchange Limited (ACE); and the Universal Commodity Exchange Ltd. (UCX). Apart from these, there are 16 regional exchanges. The Forward Markets Commission (FMC) is an independent body involved with the regulation of all commodity exchanges. Futures' trading is organized in such goods or commodities as are permitted by the government. Trading in commodity futures contracts can be done between, with and through the members of the recognized Exchanges. At present, 113 commodities are allowed for futures trading under the auspices of the commodity exchanges recognized under the F C (R) Act.

\section{OBJECTIVES OF THE STUDY}

- To study the role of Forward Markets Commission in Indian commodity markets

- To evaluate the working of Forward Markets Commission in Indian commodity market.

- To analyze the important developments of Forward Markets Commission 


\section{REVIEW OF LITERATURE}

Sathya S. (2015) in his study "A Comparative Study on Equity, Commodity, Currency Derivatives in India - Evidence from Future Market with special reference to BSE Ltd, Mumbai" examine that the Derivatives are financial contracts whose value is derived from some underlying asset. These assets can include equities and equity indices, bonds, loans, interest rates, exchange rates, commodities. The contracts come in many forms, but the more common ones include options, forwards/futures and swaps. The results shows negatively correlated with equity, commodity, and currency returns. Panda Rajesh (2014) in his study "Soybean Price Forecasting in Indian Commodity Market: An Econometric Model" examine that the Econometric analysis of the data for the seed prices of soybean helped in understanding the underlying pattern in the data. After analyzing the data of 160 observations, it's apparent that proposed model of ARIMA $(1,1,0)$ with additive seasonality predicts the nature of fluctuation and explains the underlying seasonality. This model can be used by traders, harvesters to minimize the scope for speculation and assume the change in prices of soybean seed for near future. They found that the model can also be used by regulators to predict the future prices and minimize the role of speculators who may otherwise destabilize the market pricing mechanism. Irfan ul haq and K Chandrasekhara Rao (2014) in his paper "Efficiency of Commodity Markets: A Study of Indian Agricultural Commodities" investigated the efficiency of Indian agricultural commodities futures market through the use of time series methodologies. The markets for all the ten commodities included in the study are efficient in long run. However, short run inefficiencies and pricing biases exist, which can be attributed to dynamic lag structure and slow adjustment to long run equilibrium. Singh Archana and Singh Narinder Pal (2014) in his paper "Commodity Futures Market Efficiency and Related Issues: A Review of Existing Literature" investigated the market efficiency in commodity futures markets is important to both the government and the producers/marketers in India. Moreover there are some other important issues related to market efficiency viz. effect of seasonality in agrocommodities, inflationary impact of commodity futures and volatility spillover between spot and futures market. The review showed that the results produced in available literature are often conflicting; the efficiency hypothesis is supported only for certain markets and only over some periods. Sivarethinamohan and Aranganathan P. (2013) in his paper "A Study on Investors' Preference in Indian Commodities Market" finally the research conclude with investment behavior of investors and their attitude towards commodities market investments, that is the different respondents consider the different factors to take their investment decisions particularly in commodities market investments, because it is having more both risk and return factors, if the company advice the make the respondents to know the long benefits, they will also turn their eyes on commodities market. They found that particularly the Bullions have more value and being traded in huge volume per day. Kumar Babita, Banga Gagandeep and Jindal Ajay (2012) in his paper "Perception and Attitude of Farmers and Agri Firms towards Commodity Finance" investigated the Commodity finance in case of agricultural commodities is a short term finance provided by banks to the farmers backed by the warehouse receipt which the bank uses as a collateral. The study reveals that the facility of commodity finance is better than the traditional financing facilities and farmers and agri firms who are availing this facility are overall satisfied with it as they get $75 \%$ value of the commodity as finance. Farmers need not resort to distress sale of their produce. But the interest presently charged (12-13\%) on the finance should be reduced to make it more beneficial for the farmers. Biswas Subhasis and Rajib Prabina (2011) in his paper "Testing price volume relationships for Indian commodity futures" examined in this study, they 
have considered three commodities from MCX, namely, MCX Crude Oil, MCX Gold and MCX Silver. MCX ranks No. 1 in Silver, No. 2 in Gold and No. 3 in Crude Oil in terms of the number of future contracts traded in the world in 2009. The selection of commodities is mainly because of the above fact as the objective was to select such commodities which can be compared with world commodity futures markets. Daily trading data for each futures contract have been considered for this study. As in case of Silver and Crude Oil, volume Granger causes absolute return with $F$ statistic far exceeding critical value, these two markets may be characterized by the presence of speculators in the market which has an implication for market efficiency.

\section{RESEARCH METHODOLOGY}

The study is based on secondary data and descriptive in nature. For this study has been used of secondary data, which is collected from the books related topics, magazines, articles, reputed journals, research paper, newspapers articles, websites, commodity market bulletins, annual reports of Forward Markets Commission and other publications. The various reports and records issued and maintained by the Government of India are also used in the study. Tables and Graphical methods are used for presenting and clarifying data's.

\section{SYSTEM OF REGULATION OF FORWARD/FUTURES TRADING}

At present, there are three tiers of regulations of forward/futures trading system in India, namely, government of India (Ministry of Finance), Forward Markets Commission (FMC) and commodity exchanges. The FC (R) Act, 1952 prohibits options in commodities. For the purpose of forward contracts in certain commodities can be regulated by notifying those commodities $\mathrm{u} / \mathrm{s} 15$ of the Act; forward trading in certain other commodities can be prohibited by notifying these commodities $\mathrm{u} / \mathrm{s} 17$ of the Act. The need for regulation arises on account of the fact that the benefits of futures markets accrue in competitive conditions. Proper regulation is needed to create competitive conditions. In the absence of regulation, unscrupulous participants could use these leveraged contracts for manipulating prices. This could have undesirable influence on the spot prices, thereby affecting interests of society at large. Regulation is also needed to ensure that the market has appropriate risk management system. In the absence of such a system, a major default could create a chain reaction. The resultant financial crisis in a futures market could create systematic risk. Regulation is also needed to ensure fairness and transparency in trading, clearing, settlement and management of the exchange so as to protect and promote the interest of various stakeholders, particularly non-member users of the market.

1. Government of India: The central government makes policy regarding the forward trading in commodities. At present, the Ministry of Finance, (Department of Economic Affairs) government is dealing with commodity futures trading. The Central Government broadly determines the policy relating to areas such as identification of commodities as well as the territorial area in which futures/forward trading can be permitted and giving recognition to the Exchange/ Association through which such trading is to be permitted.

2. Forward Markets Commission (FMC): The commission came into existence in 1953 under the provisions of Forward Contract (Regulation) Act, 1952. As a statutory body it functions under the administrative control of the Ministry of Finance. Administration headquarters of Forward 
Markets Commission is at Mumbai and regional office at Kolkata. The Forward Markets Commission performs the role of approving the Rules and Regulations of the Exchange in accordance to which trading is to be conducted, accords permission for commencement of trading in different contracts, monitors market conditions continuously and takes remedial measures wherever necessary.

3. Commodity Exchanges: The Recognized Exchanges/Associations provide the framework of Rules and Regulations for conduct of trading, indicate the place where the trading can be conducted, report, record, execute and settle contracts, provide forum for exchange of documents and payments, etc. Commodity Exchange works under the provisions of Forward Markets Commission. FMC is the regulatory body to control the activities of commodity exchanges just like SEBI regulates the functions of Capital Market. The Forward Markets Commission is a regulatory authority of commodity derivatives/futures market in India. FMC is the chief regulator of forward and futures markets in India. The Commission allows commodity futures/forward trading in 22 exchanges in India, of which 6 are national. The major national exchanges are (i) Multi-commodity Exchange of India Ltd. (MCX), Mumbai, (ii) National Commodity and Derivatives Exchange Ltd. (NCDEX), Mumbai (iii) National Multi-commodity Exchange of India Ltd. (NMCE), Ahemadabad, (iv) Indian Commodity Exchange Ltd. (ICEX) Mumbai, (v) Ace Derivatives \& Commodity Exchange Ltd. (ACE) Ahemadabad, and (vi) Universal Commodity Exchange Ltd. (UCX). These exchanges are recognized to regulate trading in a variety of commodities approved by Forward Markets Commission under the Forward Contracts (Regulation) Act, 1952. These on-line national commodity exchanges have been organized for conducting forward/futures trading activities in all commodities, to which section 15 of the Forward Contracts (Regulation) Act, 1952 is applicable, and other commodities subject to the approval of the Forward Markets Commission.

\section{REGULATORY FRAME WORK OF COMMODITY MARKETS IN INDIA}

\section{Forward Contract (Regulation) Act}

The Commodity Derivatives and Futures Markets are regulated according to the provisions of Forward Contract (Regulation) Act 1952. The Act broadly divides commodities into 3 categories, i.e. commodities in which forward trading is prohibited, commodities in which forward trading is regulated and residuary commodities. Under Section 17 of the F.C (R) Act, 1952, the Government has powers to notify commodities, forward trading in which is prohibited in whole or part of India. Any forward trading in such commodities in the notified area is illegal and liable to penal action. Under Section 15, Government has powers to notify commodities in which forward trading is regulated as also the area in which such regulation will be in force. Once a commodity is notified under section 15, the forward trading in such contracts (other than Nontransferable Specific Delivery Contracts) has to be necessarily between members of the recognized association or through or with any such member. Contracts other than these are illegal. Section 6 of the Act provides for powers to the Central Government to grant recognition to an association for organizing forward contracts in the commodity which is notified under Section 15. Such recognition may be for a specified period or may remain in force till revoked under Section 7 of the Act. Section 18 (1) exempts the Non-Transferable Specific Delivery Contracts from the purview of regulation. However, under Section 18 (3) of the Act, the Government has powers to 
prohibit or regulate the non-transferable specific delivery contracts in commodities also by issue of a notification. Such notifications may apply for the whole of the country or the specified part of the country. Trading in commodities where non-transferable specific delivery contracts are prohibited is illegal and liable to penal action. Trading in non-transferable specific delivery contracts in respect of regulated commodities has to be through recognized associations just as in the case of other forward contracts. The commodities that are notified neither under section 15 nor under section 17 of the Act is in common parlance referred to as free commodities. For organized forward trading in such commodities, the concerned Association or Exchange has to get a certificate of registration under Section 14B of the Act from the Forward Markets Commission.

\section{Forward Markets Commission (FMC)}

The Forward Markets Commission (FMC) is a statutory body set up in 1953 under the Forward Contracts (Regulation) Act, 1952. Forward Markets Commission (FMC), is a regulatory authority for commodity futures and derivatives market in India. It functions under the administrative control of the Department of Economic Affairs, Ministry of Finance; with it's headquartered at Mumbai and a regional office at Kolkata. The Act provides that the Commission shall consist of not less than two but not exceeding four members appointed by the Central Government, out of them one being nominated by the Central Government to be the Chairman of the Commission. Currently the Commission comprises of three members among whom Shri Ramesh Abhishek, IAS is the Chairman, Dr. M. Mathisekaran, IES and Shri Nagendraa Parakh is the Members of the Commission. Dr.M. Mathisekaran, Economic Advisor of the Commission, took over the charge of Member, Forward Markets Commission Mumbai on 16th December 2011.

The Commission functioned under the administrative control of the Ministry of Consumer Affairs, Food and Public Distribution, Department of Consumer Affairs, (Govt. of India) till $5^{\text {th }}$ September. Thereafter the Commission has been functioning under the Ministry of Finance, Department of Economic Affairs, (GOI). Vide Gazette Notification S.O. No. 2694 dated 6 September 2013 the work related to Forward Markets Commission, Futures trading and the Forward Contracts (Regulation) Act of 1952 were shifted to Department of Economic Affairs (DEA) from Department of Consumer Affairs (DCA).) It has its headquarters at Mumbai and one regional office at Kolkata. The Commission comprises of a Chairman, and two Members. The Forward Markets Commission (FMC) is a regulatory authority of commodity market in India. FMC is the chief regulator of forward and futures markets in India. The Commission allows commodity futures/forward trading in 22 exchanges in India, of which 6 are national.

\section{Administration}

The Headquarters of Forward Markets Commission (FMC) is at Mumbai and a regional office at Kolkata. The Forward Markets Commission is organized into ten administrative divisions to carry out its various tasks. Forward Markets Commission divisions are: (i) Market Division I, (ii) Market Division II (Markets, Trading and Development), (iii) Market Intelligence, Monitoring \& Surveillance Division (M \& S Division), (iv) Planning \& Co-ordination Division, (v) Legal Affairs Division, (Investigation, Vigilance and Legal Affairs) (vi) Administration Division, (Commission Secretariat including HR, Administration and Finance, Grievances) (vii) Intermediary (IR) Division, (viii) IT Division, (ix) Vigilance \& Enforcement Division, and (x) Investor Protection Division. Each Division is headed by a Director, assisted by Deputy Directors, Assistant Directors, 
Economic Officers and Junior Research Assistants. The structure of ten administrative divisions in Forward markets Commission (FMC) is as follows:

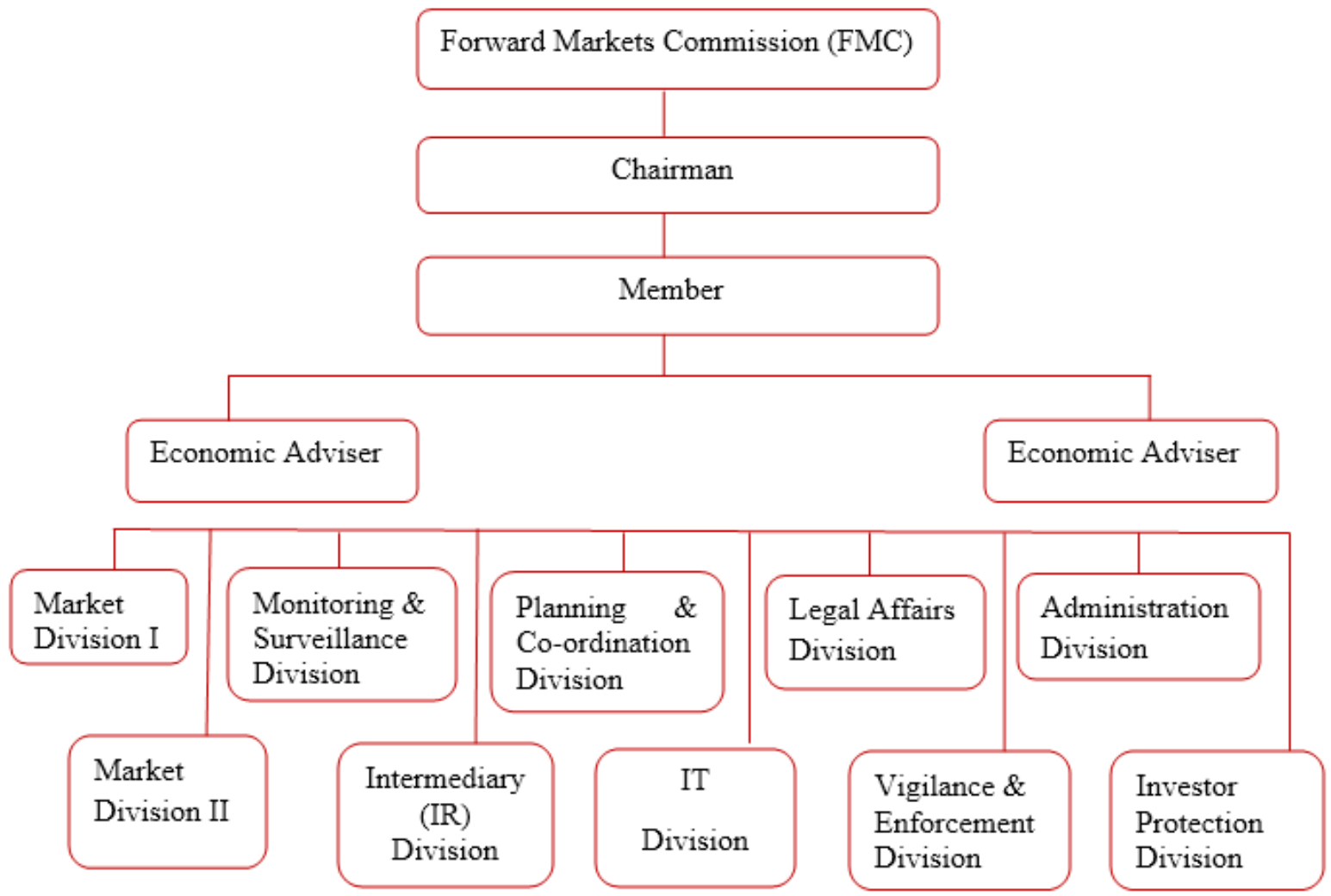

Figure 1: The structure of administrative divisions in Forward markets Commission

\section{Functions of the Forward Markets Commission}

Forward Markets Commission is a statutory body set up under Forward Contracts (Regulation) Act, 1952. The Commission functions under the administrative control of the Ministry of Finance, Department of Economic Affairs, (Government of India). The functions of the FMC are dealt with in section 4 of the Forward Contracts (Regulation) Act, 1952 [F.C (R) Act, 1952] which is given below:

- To advise the Central Government in respect of the recognition or the withdrawal of recognition from any association or in respect of any other matter arising out of the administration of the Forward Contracts (Regulation) Act 1952.

- To keep forward markets under observation and to take such action in relation to them, as it may consider necessary, in exercise of the powers assigned to it by or under the Act.

- To collect and whenever the Commission thinks it necessary, to publish information regarding the trading conditions in respect of goods to which any of the provisions of the act is made applicable, including information regarding supply, demand and prices, and to submit to the Central Government, periodical reports on the working of forward markets relating to such goods; 
- To make recommendations generally with a view to improving the organization and working of forward markets;

- To undertake the inspection of the accounts and other documents of any recognized association or registered association or any member of such association whenever it considerers it necessary.

- To perform such other duties and exercise such other powers as may be assigned to the Commission by or under this Act, or as may be prescribed.

\section{Powers of the Commission as indicated in Section 4 A of the F.C. (R) Act, 1952}

1. The Commission shall, in the performance of its functions, have all the powers of a civil court under the Code of Civil Procedure, 1908 (5 of 1908), while trying a suit in respect of the following matters, namely:

a) Summoning and enforcing the attendance of any person and examining him on oath;

b) Requiring the discovery and production of any document;

c) Receiving evidence on affidavits;

d) Requisitioning any public record or copy thereof from any office;

e) Any other matters which may be prescribed.

2. The Commission shall have the power to require any person, subject to any privilege which may be claimed by that person under any law for the time being in force, to furnish information on such points or matters as in the opinion of the Commission may be useful for, or relevant to any matter under the consideration of the Commission and any person so required shall be deemed to be legally bound to furnish such information within the meaning of Sec. 176 of the Indian Penal code, 1860 (45 of 1860).

3. The Commission shall be deemed to be a civil court and when any offence described in Sections. 175, 178, 179, 180 or Sec. 228 of the Indian Penal Code, 1860 (45 of 1860), is committed in the view or presence of the Commission, the Commission may, after recording the facts constituting the offence and the statement of the accused as provided for in the Code of Criminal Procedure, 1898 (5 of 1898) [11] forward the case to a Magistrate having jurisdiction to try the same and the Magistrate to whom any such case is forwarded shall proceed to hear the complaint against the accused as if the case had been forwarded to him under Section 482 of the said Code [12].

4. Any proceeding before the Commission shall be deemed to be a judicial proceeding within the meaning of Sections. 193 and 228 of the Indian Penal Code, 1860 (45 of 1860).

The following powers are vested in the Central Government, most of which are delegated to the Commission: The powers of approving memorandum and articles of association and Bye-laws; powers to direct to make or to make articles (Rules) or Byelaws; powers to suspend governing body of recognized association, and, powers to suspend business of recognized association. 


\section{Regulatory measures taken by FMC}

\subsection{Illegal contracts}

Following are the scenarios, in which the contracts are termed as illegal contracts,

a) Forward Contracts in the permitted commodities, i.e., commodities notified under S.15 of the Forward Contracts (Regulation) Act, 1952, which are entered into other than: (a) between the members of the recognized Association or (b) through or (c) with any such members.

b) Forward contracts in prohibited commodities, which are described under section 17 of forward contract act.

c) Forward Contracts in the commodities in which such contracts have been prohibited.

\subsection{Measures against illegal forward trading}

a) The role of Forward Markets Commission is to communicate the information relating to offences under the Act to the police authorities and assist such authorities in their work such as accompanying the police in conducting searches for documents etc.

b) The offences under the Act are technical in nature and it is difficult to prove the charges in accordance with the rules of evidence contained in the Evidence Act. So, the Forward Markets Commission periodically conducts training programs, Seminars, Workshops etc. for the benefit of Police Officers/ Prosecutors and also Judicial Magistrates First Class/Metropolitan Magistrates.

\subsection{Rules governing illegal forward contracts}

a) Owner of a place which is used for performing illegal forward contracts, with the knowledge of such owner.

b) A person who, without permission of the Central Government, organizes illegal forward contract.

c) Any person who willfully misrepresents or induces any person to believe that he is a member of a recognized association or that forward contract can be performed through him.

d) Any person who is not a member of a recognized association canvasses, advertises or touts in any business connected with forward contracts in contravention of the Forward Contracts (Regulation) Act, 1952.

e) Any person who joins, gathers, or assists in gathering at any place other than the place of business specified in the bye-laws of the recognized associations for making bids or offers or for entering into illegal forward contracts.

f) Any person who makes publishes or circulates any statement or information, which is false and which he knows to be false, affecting or tending to affect the course of business in forward contracts in permitted commodities.

\section{Limitations and Future of FMC}

This section presents limitations, various issues and challenges present in FMC and what the future of FMC is going to be. Following are the limitations of FMC

a) Option trading prohibited

b) Functions as a Government department with limited autonomy with respect to : 
1. Recognition/de-recognition of exchanges

2. Regulation of intermediaries

3. Financial and administrative autonomy

c) Market expansion has put heavy pressure on the FMC coping capacity

Table 1: List of Commodities Notified Under Section 15 of the F.C. (R.) Act 1952

113 Commodities Being Regulated under Section 15 of the FC (R), Act 1952

\begin{tabular}{|c|c|c|c|}
\hline Sl. No. & Commodity & SI. No. & Commodity \\
\hline I & Food Grains and Pulses & I & Food Grains and Pulses \\
\hline 1 & Arhar Chuni & 23 & Urad dal \\
\hline 2 & Bajra & 24 & Wheat \\
\hline 3 & Barley & II & Oilseeds and Oils \\
\hline 4 & Gram & 25 & Celery seed \\
\hline 5 & Gram Dal & 26 & Copra Oil/Coconut Oil \\
\hline 6 & Guar & 27 & Copra Oilcake / Coconut Oilcake \\
\hline 7 & Jowar & 28 & Copra/ Coconut \\
\hline 8 & Kulthi & 29 & Cotton seed \\
\hline 9 & Lakh (Khesari) & 30 & Cottonseed Oil \\
\hline 10 & Maize & 31 & Cottonseed Oilcake \\
\hline 11 & Masur & 32 & CPO Refined \\
\hline 12 & Moth & 33 & Crude Palm Oil \\
\hline 13 & Mung & 34 & Crude Palm Olive \\
\hline 14 & Mung Chuni & 35 & Groundnut \\
\hline 15 & Mung Dal & 36 & Groundnut Oil \\
\hline 16 & Peas & 37 & Groundnut Oilcake \\
\hline 17 & Ragi & 38 & Linseed \\
\hline 18 & Rice or Paddy & 39 & Linseed \\
\hline 19 & $\begin{array}{l}\text { Small Millets (Kodan Kulti, Kodra, } \\
\text { Korra, Vargu, Sawan, Rala, Kakun, } \\
\text { Samai, Vari \& Banti) }\end{array}$ & 40 & Linseed Oilcake \\
\hline 20 & Tur Dal (Arhar Dal) & 41 & Rapeseed Oil/Mustard Oil \\
\hline 21 & Tur(Arhar) & 42 & $\begin{array}{l}\text { Rapeseed Oilcake/ Mustard } \\
\text { seed Oilcake }\end{array}$ \\
\hline 22 & Urad (Mash) & 43 & Rapeseed/Mustard seed \\
\hline II & Oilseeds and Oils & III & Spices \\
\hline 44 & RBD Palmolein & 66 & Coriander seed \\
\hline 45 & Rice Bran & 67 & Ginger \\
\hline 46 & Rice Bran Oil & 68 & Methi \\
\hline 47 & Rice Bran Oilcake & 69 & Nutmegs \\
\hline 48 & Safflower & 70 & Pepper \\
\hline 49 & Safflower Oil & 71 & Turmeric \\
\hline 50 & Safflower Oilcake & IV & Metals \\
\hline 51 & Sesame (Til) & 72 & Copper \\
\hline 52 & Sesame Oil & 73 & Zinc \\
\hline 53 & Sesame Oilcake & 74 & Lead \\
\hline
\end{tabular}




\begin{tabular}{|c|c|c|c|}
\hline 54 & Soy meal & 75 & Tin \\
\hline 55 & Soy Oil & 76 & Gold \\
\hline 56 & Soybean & 77 & Silver \\
\hline 57 & Sunflower Oil & 78 & Silver Coins \\
\hline 58 & Sunflower Oil cake & $\mathbf{V}$ & Fibres and Manufactures \\
\hline 59 & Sunflower Seed & 79 & Art Silk Yarn \\
\hline III & Spices & 80 & Cotton Cloth \\
\hline 60 & Aniseed & 81 & Cotton pods \\
\hline 61 & Betel nuts & 82 & Cotton Yarn \\
\hline 62 & Cardamom & 83 & $\begin{array}{l}\text { Indian Cotton (Full pressed, half } \\
\text { pressed or loose) }\end{array}$ \\
\hline 63 & Chillies & 84 & $\begin{array}{l}\text { Jute goods (Hessian and Sackings } \\
\text { and cloth and /or bags, twines and/or } \\
\text { yarns mfd. by any of the mills and/or } \\
\text { any other manufacturers of whatever } \\
\text { nature made from jute) }\end{array}$ \\
\hline 64 & Cinnamon & 85 & Kapas \\
\hline 65 & Cloves & 86 & Raw Jute Including Mesta \\
\hline $\mathbf{V}$ & Fibres and Manufactures & VI & Others \\
\hline 87 & Staple Fiber Yarn & 100 & Sugar \\
\hline VI & Others & 101 & Furnace Oil \\
\hline 88 & Camphor & 102 & Ethanol \\
\hline 89 & Castor seed & 103 & Cooking Coal \\
\hline 90 & $\begin{array}{l}\text { Chara or Berseem (including } \\
\text { chara seed or berseem seed }\end{array}$ & 104 & Electricity \\
\hline 91 & Crude Oil & 105 & Natural Gas \\
\hline 92 & Gram Husk (Gram Chilka) & 106 & Onion \\
\hline 93 & Gur & 107 & Carbon Credit \\
\hline 94 & Khandsari Sugar & 108 & Thermal coal \\
\hline 95 & Polymer & 109 & Methanol \\
\hline 96 & Potato & 110 & Melted Menthol Flakes \\
\hline 97 & Rubber & 111 & Mentha Oil \\
\hline 98 & Seedlac & 112 & Menthol Crystals \\
\hline 99 & Shellac & 113 & Iron Ore \\
\hline
\end{tabular}

Major Initiatives taken by the Government/Commission since liberalization of the market

- Prohibition on futures trading lifted in all the commodities on 1st April 2003.

- Three Multi-Commodity electronic Exchanges, i.e., National Multi Commodity Exchange, Ahmedabad (10.1.2003), Multi Commodity Exchange, Mumbai (26.9.2003) and National Commodity and Derivative Exchange, Mumbai (20.11.2003) were granted recognition as 'National' Exchanges during 2003.

- After a ban of more than four decades, futures trading in gold and silver for the first time commenced at National Multi Commodity Exchange, Ahmedabad on 3.10.2003. Multi Commodity Exchange, Mumbai and National Commodity and Derivative Exchange, 
Mumbai also launched futures trading in gold and silver on 10.11.2003 and 15.12.2003 respectively.

- Fourth National Exchange viz. Indian Commodity Exchange Limited (ICEX) was granted recognition on the $9^{\text {th }}$ October 2009 on permanent basis.

- Fifth National Exchanges namely, ACE Commodity and Derivative Exchanges was granted recognition on 10.8.2010. ACE became a National Exchange by upgrading itself from a Regional Exchange.

- On 14th May 2008, the Commission issued guidelines on setting up of new National Multi Commodity Exchanges to further strengthen the infrastructure in Commodity Derivative Market. Inter alia, it prescribed the framework for share holding pattern of a new National Multi Commodity Exchange. A sixth National Commodity Exchanges namely, Universal Commodity Exchanges was granted recognition on $30^{\text {th }}$ August, 2012. Universal Commodity Exchange Ltd (UCX), Mahape, Navi Mumbai on a permanent basis in respect of forward contracts in all the commodities in which Section 15 is applicable and the commodities to which neither Section 17 nor Section 15 of the Forward Contracts (Regulation) Act, is applicable. These exchanges can offer futures contracts in all the commodities subject to the approval of the Commission. Besides these, there are 16 other exchanges recognized for futures trading in specific commodities, generally referred to as Regional Exchanges.

- Improvement of Regulatory Framework and Re-structuring of Forward Markets Commission: The F.C (R) Act enacted in 1952 does not meet the regulatory needs of a modern electronic market. Hence, the regulatory framework needs to be overhauled to bring it on par with those of similar regulators like SEBI, etc. and also to restructure and strengthen the Forward Markets Commission to meet the regulatory challenges. Hence, a Bill proposing amendments to F.C (R) Act has been approved by the Cabinet which, inter alia, provides for -

$>$ Defining forward contract so as to include other commodity derivatives, definition of intermediaries, etc.

$>$ Composition and functioning of FMC.

$>$ Financial and administrative autonomy of the Commission so as to provide for recruitment of its officers and its employees, management of the affairs to vest with the Chairman, accounts and audits, and creation of an 'FMC General Fund' to which all receivables except penalties will be credited. The FMC General Fund shall be used for the management of the affairs of the Commission and to enforce the provisions of the F.C (R) Act, 1952.

$>$ Levying of fees on intermediaries to finance the Commission activities.

$>$ Allowing trading of options and other derivatives in goods.

$>$ Provide for corporatization and demutualization of commodity exchanges.

$>$ Strengthening the penal provisions.

$>$ Constitution of Forward Markets Appellate Tribunal.

$>$ Provision for grant by the Central Government to meet transitional financial needs of FMC. 


\section{Initiatives taken by the Forward Markets Commission}

It may be mentioned that in the Commodity Futures Market, the products currently permitted are futures and forward. "Options" have not been permitted. In order to ensure that the stakeholders have a proper understanding of the functioning of commodity markets, the Commission has undertaken various initiatives such as awareness programmes, capacity building programmes, internships and other activities for raising awareness about the commodity futures market build capacities among the stakeholders. The details of the initiatives during the past five years are indicated below:

Table 2: Awareness programmes, Capacity building programmes, Stakeholder meetings, Summer Internships and other activities of Forward Markets Commission

\begin{tabular}{|l|l|l|l|l|l|}
\hline Year & $\begin{array}{l}\text { Awareness } \\
\text { Programmes }\end{array}$ & $\begin{array}{l}\text { Capacity } \\
\text { Building } \\
\text { Programmes }\end{array}$ & $\begin{array}{l}\text { Stakeholder } \\
\text { Meetings }\end{array}$ & $\begin{array}{l}\text { Summer } \\
\text { Internship }\end{array}$ & $\begin{array}{l}\text { Participation } \\
\text { in Exhibition/ } \\
\text { Expos etc }\end{array}$ \\
\hline $2007-08$ & 114 & 8 & 6 & -- & -- \\
\hline $2008-09$ & 197 & 18 & 6 & -- & 1 \\
\hline $2009-10$ & 515 & 63 & 8 & $\begin{array}{l}15 \text { students }(7 \\
\text { Institutes })\end{array}$ & 2 \\
\hline $201-11$ & 829 & 79 & 5 & -- & 2 \\
\hline $2011-12$ & 818 & 100 & 10 & $\begin{array}{l}5 \text { students ( } 3 \\
\text { institutes })\end{array}$ & 3 \\
& & & & -- & 2 \\
\hline $2012-13$ & 872 & 100 & 15 & -- & 2 \\
\hline $2013-14$ & 1027 & 103 & 15 & & \\
\hline
\end{tabular}

\section{Initiatives of the Forward Markets Commission in 2013-14}

Settlement Guarantee Fund: The Commission had issued guidelines regarding set ting up of Settlement Guarantee Fund (SGF) in 2007. The SGF was operationalized in 2013 and the exchanges transferred INR $460.13 \mathrm{Cr}$. to SGF corpus as on 31/3/2014. This is a very important risk management initiative which has inspired much confidence among the market participants.

Corporate Governance: To strengthen corporate governance of the National Commodity Exchanges the Commission issued revised Guidelines to have a broad-based representation of all classes of shareholders on the Board of Directors of the Exchanges. This will improve Corporate Governance at the Exchanges and make Board of Directors more responsive and broad based, eliminating the dominance of non-institutional shareholders.

Strengthening of warehousing facilities: The Commission decided that all the existing warehouses accredited by the Exchanges shall be registered with Warehousing Development and Regulatory Authority (WDRA) in a time-bound manner. This will strengthen the warehousing facility in the Commodity Futures market. 
Risk Management Group: A Risk Management Group (RMG) was constituted to assist the Commission in formulating risk management policies and guidelines for Commodities Derivatives Market. RMG is chaired by Prof. J. R. Verma, IIM, Ahmedabad.

Incentives to hedgers: To reduce the cost of hedging, the Exchanges were directed to exempt the market participants, who have deposited certified goods against all the relevant futures contracts sold and earmarked for delivery, to the Exchange accredited warehouse, from paying initial, additional and special margins. Such participants will continue to remain exempted from payment of delivery margins. Besides, the Commission also permitted spread margin benefits to those having different month contracts of the same underlying commodity and to those having two contract variants having the same underlying commodity.

Margin Reporting: In order to regularly monitor the collection of margins by members and also provide a reasonable time to members for collection of margins from their clients, the Commission on $14^{\text {th }}$ March, 2014 revised its earlier instructions on short-collection/ non- collection of margins, so that the members will have time till ' $\mathrm{T}+2$ ' working days to collect margins (except initial margins) from their clients and the Member shall report to the Exchange on $T+5$ day the actual short collection/non collection of all margins from clients.

Approval of futures contracts on continuous basis: The Commission decided to grant continuous approval for trading in the futures contracts instead of the practice of giving permission for trading in futures contracts on yearly basis.

Consumer Protection - As a part of implementation of non-legislative recommendations of FSLRC, FMC adopted enhanced consumer protection measures which include requirement of professional diligence on the part of members and protection of consumers from unfair terms in financial contracts.

Table 3: Milestones of the Forward Markets Commission

\begin{tabular}{|c|c|}
\hline 1875 & Bombay Cotton Trade Association \\
\hline Between $1^{\text {st }}$ and $2^{\text {nd }}$ World war & Rapid growth of futures markets \\
\hline $\begin{array}{l}\text { During } 2^{\text {nd }} \\
\text { World War }\end{array}$ & $\begin{array}{l}\text { Defence of India Act- Prohibited Futures } \\
\text { trading in major Commodities owing to short } \\
\text { supply. }\end{array}$ \\
\hline 1950s to mid-1960s & Thriving Commodity futures markets \\
\hline Mid 1960s to $1970 \mathrm{~s}$ & $\begin{array}{l}\text { Banned Commodity Futures trading in most } \\
\text { of the Commodities except two minor } \\
\text { Commodities - Pepper and Turmeric. }\end{array}$ \\
\hline $1980 \mathrm{~s}$ & $\begin{array}{l}\text { Revival of Futures trading in Potato, Castor } \\
\text { Seed and Gur (Jaggery). }\end{array}$ \\
\hline 1992 & Futures trading in Hessian permitted. \\
\hline 1999 & $\begin{array}{l}\text { Futures trading in various edible oilseeds } \\
\text { complexes permitted. }\end{array}$ \\
\hline 2000 & $\begin{array}{l}\text { The National Agricultural Policy-recognized } \\
\text { the positive role of forward and futures }\end{array}$ \\
\hline
\end{tabular}




\begin{tabular}{|c|c|}
\hline & $\begin{array}{l}\text { markets in price discovery and price risk } \\
\text { management. }\end{array}$ \\
\hline 2001 & Futures trading in Sugar permitted. \\
\hline \multirow[t]{2}{*}{2003} & $\begin{array}{l}\text { Lifted prohibition on futures trading in all } \\
\text { Commodities }\end{array}$ \\
\hline & $\begin{array}{l}\text { Recognition to } 3 \text { National Commodity } \\
\text { Electronic Exchanges MCX, NCDEX and } \\
\text { NMCE. }\end{array}$ \\
\hline 2008 & $\begin{array}{l}\text { Commission issued guidelines on setting up } \\
\text { of New National Multi Commodity } \\
\text { Exchanges. }\end{array}$ \\
\hline 2009 & $\begin{array}{l}\text { Recognition to ICEX as } 4^{\text {th }} \text { National } \\
\text { Exchange }\end{array}$ \\
\hline \multirow[t]{2}{*}{2010} & $\begin{array}{l}\text { Recognition to ACE as } 5^{\text {th }} \text { National } \\
\text { Exchange. }\end{array}$ \\
\hline & $\begin{array}{l}\text { Notified "Iron Ore" under section } 15 \text { of the } \\
\text { FCRA, } 1952 \text {. }\end{array}$ \\
\hline 2012 & $\begin{array}{l}\text { Recognition to UCX as } 6^{\text {th }} \text { National } \\
\text { Exchange. }\end{array}$ \\
\hline
\end{tabular}

\section{IMPORTANT DEVELOPMENTS IN THE FORWARD MARKETS COMMISSION}

Table 4: Years-wise Developments in Commodity Futures Market of India

\begin{tabular}{|l|l|l|}
\hline Years & $\begin{array}{l}\text { Value of Trade } \\
\text { (In Crore) }\end{array}$ & $\begin{array}{l}\text { Traded Volume } \\
\text { (In Lakh tonnes) }\end{array}$ \\
\hline $2009-10$ & 7764754.050 & 10142.93 \\
\hline $2010-11$ & 11948942.35 & 12805.57 \\
\hline $2011-12$ & 18126103.78 & 14025.74 \\
\hline $2012-13$ & 17046840.09 & 14510.08 \\
\hline $2013-14$ & 10144794.98 & 8832.76 \\
\hline
\end{tabular}

Source: Forward Markets Commission (FMC), ww.fmc.gov.in, (Government of India)

The table 4 shows the developments of commodity futures market in India during the year 200910 to 2013-14. The total value of trading in the commodity futures market rose from Rs. 7764754.050 crore in 2009-10 to Rs. 18126103.78 crore in 2011-12; whereas value of trade continuously decreased from Rs. 17046840.09 crore in 2012-13 to Rs. 10144794.98 crore in 201314. The total volume of trade in commodity futures market increased from 10142.93 lakh tonne in 2009-10 to 14510.08 lakh tonnes in 2012-13, while volume of trade decreased to 8832.76 lakh tonne in 2013-14. 


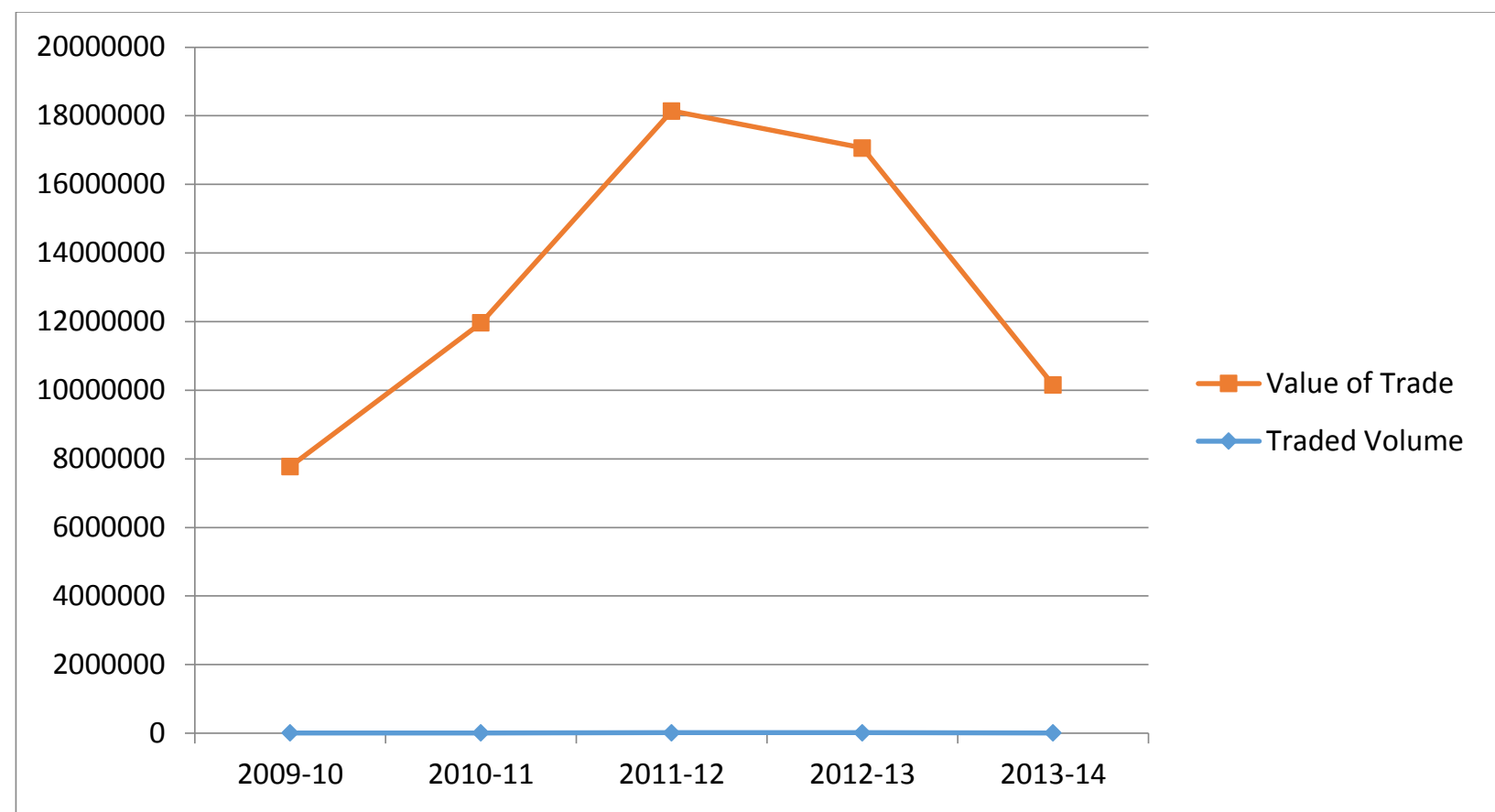

Figure 2: Annual growth of Commodity Futures Market in 2009-10 to 2013-14

Source: Forward Markets Commission (FMC), ww.fmc.gov.in, (Government of India)

The figure 2 shows the annual growth of commodity futures market in India during the 2009-10 to 2013-14, which indicates an increasing and decreasing trend in value of trade and traded volume of traded commodities. The value of trade was Rs. 7764754.050 crore in 2009-10 which increases to Rs. 18126103.78 crore in 2011-12, similarly value of trade Rs. 17046840.09 crore in 2012-13 decreases to Rs. 10144794.98 crore in 2013-14. Whereas, volume of trade 10142.93 lakh tone in 2009-10 increases to 14510.08 lakh tones in 2012-13; and then decreases to 8832.76 lakh tonne in 2013-14. Agricultural commodities, bullion, base metals and energy products accounted for a large share of the commodities traded in the commodity futures market.

\section{Major Group of Commodities traded during the year 2009-10 to 2013-14}

Table 5: Commodity Group-wise Developments in Commodity Market of India Value of Trade (In Rs. Cr.)

\begin{tabular}{|c|c|c|c|c|c|c|c|c|c|c|}
\hline \multirow{2}{*}{$\begin{array}{l}\text { Comm } \\
\text { odity } \\
\text { Group } \\
\text { s } \\
\end{array}$} & \multicolumn{2}{|l|}{ 2009-10 } & \multicolumn{2}{|l|}{ 2010-11 } & \multicolumn{2}{|l|}{ 2011-12 } & \multicolumn{2}{|l|}{ 2012-13 } & \multicolumn{2}{|l|}{ 2013-14 } \\
\hline & Value & Vol. & Value & Vol. & Value & Vol. & Value & Vol. & Value & Vol. \\
\hline $\begin{array}{l}\text { Bullio } \\
\mathrm{n}\end{array}$ & $\begin{array}{l}3164152.24 \\
(40.75)\end{array}$ & $\begin{array}{l}4.73 \\
(0.05) \\
\end{array}$ & $\begin{array}{l}5493892.12 \\
(45.98)\end{array}$ & $\begin{array}{l}7.38 \\
(0.06) \\
\end{array}$ & $\begin{array}{l}10181957.22 \\
(56.17) \\
\end{array}$ & $\begin{array}{l}10.27 \\
(0.07) \\
\end{array}$ & $\begin{array}{l}7862678.65 \\
(46.12)\end{array}$ & $\begin{array}{l}7.28 \\
(0.05) \\
\end{array}$ & $\begin{array}{l}4308937.82 \\
(42.37)\end{array}$ & $\begin{array}{l}4.03 \\
(0.05) \\
\end{array}$ \\
\hline $\begin{array}{l}\text { Base } \\
\text { Metals }\end{array}$ & $\begin{array}{l}1801636.31 \\
(23.20)\end{array}$ & $\begin{array}{l}981.92 \\
(9.68)\end{array}$ & $\begin{array}{l}2687672.99 \\
(22.49)\end{array}$ & $\begin{array}{l}1409.72 \\
(11.01)\end{array}$ & $\begin{array}{l}2896720.73 \\
(15.98)\end{array}$ & $\begin{array}{l}1387.85 \\
(9.90)\end{array}$ & $\begin{array}{l}3260050.77 \\
(19.12)\end{array}$ & $\begin{array}{l}742.76 \\
(12.01)\end{array}$ & $\begin{array}{l}1761359.89 \\
(17.36)\end{array}$ & $\begin{array}{l}978.3 \\
7 \\
(11.08\end{array}$ \\
\hline $\begin{array}{l}\text { Agricu } \\
\text { lture }\end{array}$ & $\begin{array}{l}1217949.04 \\
(15.69)\end{array}$ & $\begin{array}{l}3991.21 \\
(39.35)\end{array}$ & $\begin{array}{l}1456389.62 \\
(12.19)\end{array}$ & $\begin{array}{l}4168.35 \\
(32.55)\end{array}$ & $\begin{array}{l}2196149.50 \\
(12.12)\end{array}$ & $\begin{array}{l}4942.09 \\
(35.23)\end{array}$ & $\begin{array}{l}2155700.42 \\
(12.65)\end{array}$ & $\begin{array}{l}4398.11 \\
(30.31)\end{array}$ & $\begin{array}{l}1602401.96 \\
(15.80)\end{array}$ & $\begin{array}{l}3612 . \\
03 \\
(40.89\end{array}$ \\
\hline Energy & $\begin{array}{l}1577882.06 \\
(20.32)\end{array}$ & $\begin{array}{l}5162.95 \\
(50.90)\end{array}$ & $\begin{array}{l}2310958.58 \\
(19.34)\end{array}$ & $\begin{array}{l}7220.12 \\
(56.38)\end{array}$ & $\begin{array}{l}2851268.52 \\
(15.73)\end{array}$ & $\begin{array}{l}7685.52 \\
(54.80)\end{array}$ & $\begin{array}{l}3768408.97 \\
(22.11)\end{array}$ & $\begin{array}{l}8361.92 \\
(57.63)\end{array}$ & $\begin{array}{l}2472095.31 \\
(24.37)\end{array}$ & $\begin{array}{l}4238 . \\
33\end{array}$ \\
\hline
\end{tabular}




\begin{tabular}{|c|c|c|c|c|c|c|c|c|c|c|}
\hline & & & & & & & & & & $\begin{array}{l}(47.98 \\
)^{2}\end{array}$ \\
\hline Others & $\begin{array}{l}3134.40 \\
(0.04)\end{array}$ & $\begin{array}{l}2.12 \\
(0.02)\end{array}$ & $\begin{array}{l}29.04 \\
(0.00)\end{array}$ & $\begin{array}{l}0.00 \\
(0.00)\end{array}$ & $\begin{array}{l}7.80 \\
(0.00) \\
\end{array}$ & $\begin{array}{l}0.01 \\
(0.00)\end{array}$ & $\begin{array}{l}1.28 \\
(0.00)\end{array}$ & $\begin{array}{l}0.01 \\
(0.00)\end{array}$ & $\begin{array}{l}0.00 \\
(0.00)\end{array}$ & $\begin{array}{l}0.00 \\
(0.000\end{array}$ \\
\hline Total & $\begin{array}{l}7764754.05 \\
(100.00)\end{array}$ & $\begin{array}{l}10142.93 \\
(100.00)\end{array}$ & $\begin{array}{l}11948942.35 \\
(100.00)\end{array}$ & $\begin{array}{l}12805.57 \\
(100.00)\end{array}$ & $\begin{array}{l}\text { 18126103.78 } \\
(100.00)\end{array}$ & $\begin{array}{l}14025.74 \\
(100.00)\end{array}$ & $\begin{array}{l}\text { 17046840.09 } \\
(100.00)\end{array}$ & $\begin{array}{l}14510.08 \\
(100.00)\end{array}$ & $\begin{array}{l}\text { 10144794.98 } \\
(100.00)\end{array}$ & $\begin{array}{l}8832 . \\
76 \\
(100.0 \\
0)\end{array}$ \\
\hline
\end{tabular}

Source: Forward Markets Commission (FMC), website: www.fmc.gov.in

*Figures in brackets indicates per cent to total

The table 5 clearly shows the commodity group-wise value of trade and traded volume in Indian commodity futures market in India during the year 2009-10 to 2013-14. In the year 2009-10, the total value of trade in the commodity markets was Rs. 7764754.05 crore which was shared by Bullion Rs. 3164152.24 (40.75\%), Base metals Rs. 1801636.31 (23.20\%), 1217949.04 (15.69\%) and Energy 1577882.06 (20.32\%) respectively. During the year 2010-11, the total value of trade in commodity futures market was around Rs. 11948942.35 crore, this total consisted of Bullion Rs. 5493892.12 (45.98\%), Base metals Rs. 2687672.99 (22.49\%), Agriculture 1456389.62 (12.19\%) and Energy Rs. 2310958.58 (19.34\%). In 2011-12, the total value of trade in commodity futures market was Rs. 18126103.78 crore, in this, overall share of Bullion Rs. 10181957.22 (56.17\%), Base metals Rs. 2896720.73 (15.98\%), Agriculture Rs. 2196149.50 (12.12\%) and Energy Rs. 2851268.52 (15.73\%). For the year 2012-13, total value of trade in commodity futures market was Rs. 17046840.09, in this included Bullion Rs. 7862678.65 (46.12\%), Base metals Rs. 3260050.77 (19.12\%), agriculture Rs. 2155700.42 (12.65\%) and Energy Rs. 3768408.97 (22.11\%). In the year 2013-14, the total value of trade in futures trading was Rs. 10144794.98, this total included Bullion Rs. 4308937.82 (42.37\%), Base metal Rs. 1761359.89 (17.36\%), Agriculture Rs. 1602401.96 (15.80\%) and Energy Rs. 2472095.31 (24.37\%). The commodity futures market continuously increased in 2009-10 to 2011-12, and similarly decreased during the year 2012-13 to 2013-14.

\section{CONCLUSIONS}

In this study, the roles of Forward Markets Commission (FMC) in Indian commodity markets have been analyzed. This includes functions, powers and limitations of Forward Markets Commission, the various types of commodities that Forward Markets Commission regulates and different commodity exchanges present in India. There are many issues and challenges present in current structure of Forward Markets Commission.(FMC) Forward Contract (Regulation) Act was established in 1952 and isn't able to cope with these challenges. There is need of amendment in Forward Contract (Regulation) Act. Government is taking various initiatives to resolve the issues. We mentioned the future plans that will be taken by Government for the improvement in current Forward Markets Commission (FMC). The Forward Markets Commission (FMC) is a regulatory authority of commodity market in India. Forward Markets Commission (FMC) is the chief regulator of forward and futures trading in India. There are 22 Commodity Exchanges (6 National and 16 Regional Commodity Exchanges) recognized by Forward Markets Commission (FMC) in India where 113 commodities (Agricultural and Non-Agricultural Commodities) are traded. The study found out that the important developments of Forward markets Commission (FMC) in Indian commodity markets. 


\section{REFERENCES}

[1] Sendhil R., Kar Amit, Mathur V.C. and Jha Girish K. (2013) "Price Discovery, Transmission and Volatility: Evidence from Agricultural Commodity Futures" Agricultural Economics Research Review, Vol. 26 (No.1) January-June 2013 pp 41-54.

[2] Kumar Babita, Banga Gagandeep and Jindal Ajay (2012) "Perception and Attitude of Farmers and Agri Firms towards Commodity Finance" ISSN: 0971-1023, NMIMS Management Review, Volume XXII October - November 2012, pp. 89-111.

[3] Palakkod Suhail (2012) "Integration of Capital, Commodity and Currency Markets: A Study on Volatility Spillover" The Romanian Economic Journal, Year XV, No. 44, June 2012, pp. 87-100.

[4] Annual Report, Forward Markets Commission (FMC), Food and Public Distribution, Department of Consumer Affairs, Ministry of Consumer Affairs.

[5] Chatnani, Niti Nandini (2010), “Commodity Markets: Operations, Instruments, and Applications", Tata McGraw Hill, New Delhi

[6] Dhankhar J. N. (2010), "The Indian Commodity Futures Market”, Skylark Publication, New Delhi.

[7] Panda Rajesh (2014) "Soybean Price Forecasting in Indian Commodity Market: An Econometric Model" Journal of Academia and Industrial Research (JAIR), ISSN: 2278 5213, Volume 3, Issue 1 June 2014, pp. 58-62.

[8] Irfan ul haq and K Chandrasekhara Rao (2014) "Efficiency of Commodity Markets: A Study of Indian Agricultural Commodities" Pacific Business Review International, Volume 7, Issue 2, August 2014, pp. 94-99.

[9] Dr. Shree Bhagwat, Angad Maravi, Ritesh Omre, and Deepak Chand (2015) "Commodity Futures Market in India: Development, Regulation and Current Scenario”, Journal of Business Management \& Social Sciences Research (JBM\&SSR), Volume 4, No.2, February 2015.

[10] Sathya S. (2015) "A Comparative Study on Equity, Commodity, Currency Derivatives in India - Evidence from Future Market with special reference to BSE Ltd, Mumbai" International Journal of scientific research and management (IJSRM), Volume 3, Issue 2, Pp. 2175-2182, Website: www.ijsrm.in ISSN (e): 2321-3418.

[11] Dr. Shree Bhagwat, Angad Maravi, Ritesh Omre, and Deepak Chand (2015) "A Study of Historical Background of Indian Commodity Market”, EPRA International Journal of Economic and Business Review, Volume-3, Issue-3, March 2015.

[12] Singh Archana and Singh Narinder Pal (2014) "Commodity Futures Market Efficiency and Related Issues: A Review of Existing Literature" Asian Journal of Business and Economics, ISSN: 2231-3699, Volume 4, No.4.4 Quarter IV 2014, pp. 1-21.

[13] Madhu Sudan Kumar, Shom P. Das and Motahar Reza (2013) "Effect of Return and Volatility Calculation on Option Pricing: Using BANKNIFTY” International Journal of Innovation, Management and Technology, Vol. 4, No. 4, August 2013, pp. 443-446.

[14] Sarangdevot Shiv Singh, and Rathore Yuvraj Singh (2014) "Growth \& Future of Derivatives in India: A Study" Int'l Journal of Computing, Communications \& Instrumentation Engg. (IJCCIE) Volume 1, Issue 1 (2014) ISSN 2349-1469 EISSN 23491477, pp. 12-17. 
[15] Kumar Brajesh and Pandey Ajay "Role of Indian Commodity Derivatives Market in Hedging Price Risk: Estimation of Constant and Dynamic Hedge Ratio, and Hedging Effectiveness" INDONESIAN CAPITAL MARKET REVIEW •Volume 3 • No. 1, pp. 59-80.

[16] Singhal Krishna (2014) "Lead Lag Relationship between Spot and Future Price of Crude Oil in India” International Journal of Research \& Development in Technology and Management Science - Kailash, ISBN - 978-1-63102-445-0, Vol. - 21, Iss. 1, March 2014.

[17] Sivarethinamohan and Aranganathan P. (2013) in his paper "A Study on Investors" Preference in Indian Commodities Market" European Journal of Commerce and Management Research (EJCMR), Vol-2, Issue 1 www.ejcmr.org January 2013, pp. 9-15.

[18] Nissar A. Barua and Devajit Mahanta (2012) "Indian Commodity Derivatives Market and Price Inflation” IOSR Journal of Business and Management (IOSRJBM), ISSN: 2278487X, Volume 1, Issue 6, (July-August 2012), pp. 45-59.

[19] Biswas Subhasis and Rajib Prabina (2011) "Testing price volume relationships for Indian commodity futures”, Journal of Indian Business Research, Volume 3, Issue 2, available at; http://dx.doi.org/10.1108/17554191111132233, pp. $117-131$.

[20] Ray Saon and Malik Neha (2014) "Impact of Transaction Taxes on Commodity Derivatives Trading in India”, Indian Council For Research on International Economic Relations, Working Paper 272, March 2014, pp. 1-25.

[21] S.N. Sangeetha (2015) "Role of Forward Market Commission Regulations of Commodity Derivative Markets in India" Journal for Advanced Research in Commerce and Management Studies, E-ISSN: 2394-837X, Vol.2.Issue.2.2015, available at; http://www. jarcms.sspublications.co.in, pp. 19-48.

[22] S Poornima, and Deepthy K (2015) "Commodity Market in India” International Journal of Multidisciplinary Research and Development, Online ISSN: 2349-4182 Print ISSN: 2349-5979, Volume 2; Issue 11; November 2015, pp. 31-35. 